\title{
A structural model of total quality management, kaizen, operational performance on service quality and patient satisfaction
}

\author{
Indra Abadi \\ Lecturer in Management Science of \\ STIE Wira Bhakti Makassar \\ Murdifin Haming \\ Professor in Management, Postgraduate School, \\ Moslem University of Indonesia, Makassar \\ Baharuddin S. \\ Professor in Management, Postgraduate School, \\ Moslem University of Indonesia, Makassar \\ Amir Mahmud \\ Lecturer in Management, Postgraduate School, \\ Moslem University of Indonesia, Makassar
}

\begin{abstract}
Tests are the strength effect of total quality management (TQM), Kaizen and operational performance on service quality and patient satisfaction. The other part we will test is the service quality as a mediation role to explain the effect of total quality management (TQM), Kaizen and operational performance on patient satisfaction. This research was conducted in the city of Makassar with the entire population is a patient. By using the formula Slovin, found a sample of 398 respondents. Inferential statistical analysis was used to test the hypothesis of the research is Structural Equation Modeling (SEM). The results of this study indicate that TQM, Kaizen and operational performance have been shown to contribute significantly positively on service quality and patient satisfaction. The role of service quality is proven to be a mediating variable in analyzing TQM, Kaizen and operational performance effect on patient satisfaction.
\end{abstract}

Keywords: total quality management, kaizen, operational performance, service quality, patient satisfaction.

\section{INTRODUCTION}

The service sector today has experienced a dramatic increase and has a significant role in the world economy. This can be seen from the contribution of an average of more than two-thirds of the gross domestic product (GDP) of world countries (WTO, 2010). The contribution of the service sector to GDP in Indonesia is quite significant, which is around $39,10 \%$, although it is still lower than neighboring countries in Southeast Asia, such as Malaysia (48, 10\%), Philippines (57.20\%), and Singapore (70,60\%) (Central Intelligence Agency (CIA), 2018). The hospital is a non-profit organization, providing hospital health services in Indonesia to the community is guaranteed by a national health system called the National Health Insurance (JKN) managed by the Agency Health Insurance Provider (BPJS). Along with the implementation of BPJS Health in the community, Based on the facts there were found various problems related to hospital services, such as: the neglect of BPJS patients when seeking treatment at health centers and hospitals; the difficulty of finding a hospital treatment room; 
slow handling of BPJS patients, medical equipment is very limited. These problems indicate that the quality of services in hospitals is still low.

The services quality by hospitals in Indonesia provided is still less than overseas hospitals such as Malaysia and Singapore. The results of research conducted by the sumatera province research and development agency, that there are several main factors that cause Indonesian people to tend to seek treatment abroad, namely internal factors, such as the need for excellent services, and externals, such as the ability to provide better services by hospitals to its patients (Ministry of Health of the Republic of Indonesia, 2013). Assessment of service quality from the patient's perspective has been operationalized as patient satisfaction (Ygge \& Arnetz, 2001). To create patient satisfaction, then one approach is effective and practical and widely adopted by hospitals is an total approach to total quality management (TQM) (Yang, 2003). Patient satisfaction is the core in TQM wheels (Deming, 1950). Patient demand that is constantly changing causes hospitals to strive to maintain and improve service quality through continuous quality improvement (Kaizen) (Imai, 2001). Continuous improvement involves all shareholders in each hospital service process. Without these two activities, the desire to give satisfaction to patients will be difficult to achieve (Deming, 1950).

Kaizen work culture in micro system was first implemented using a concept that includes planning PDCA (plan), action (do), check (check), and follow-up (action). The PDCA concept, illustrates that each process is carried out with careful planning, measurable and clear implementation, accurate evaluation and analysis of data, and corrective actions that are in accordance with the monitoring of its implementation so that it can really solve the problems that occur in the hospital (Imai, 2001). Kaizen focuses on improving the quality of processes in a health organization through reducing cycle times, operating costs, creating continuous flow, patient satisfaction and eliminating waste (Hyland et al., 2004). Managing the right of human resources is the most important dimension in Kaizen implementation. Operational performance is one indicator of the measurement of the success of human resource management. Operational performance is part of hospital performance (Li et al., 2006; Jahanshahi et al., 2012). The main advantage of using operational measurements is when available information is related to existing opportunities, but has not been realized financially (Carton, 2004). Operational performance has various dimensions of measurement such as quality, cost, reliability, speed, and flexibility (Slack et al., 2010).

The successful implementation of TQM contributes to improving patient satisfaction, improving service quality, improving performance, and reducing hospital operating costs. The results of this study also show that top management commitment, team work and participation, process management, customer focus and satisfaction, resource management, organizational and cultural behavior, continuous improvement, and training and education are the best TQM principles applied to hospitals (Talib et al., 2011). Kaizen and TQM implementations can be increase employee motivation and shorter waiting times, but significant differences are not identified in patient satisfaction (Take et al., 2015). Increasing employee motivation is a factor that causes operational performance to have a significant positive effect on customer loyalty. Speed, quality, and dependence is an indicator of operational performance resulting in customer satisfaction and customers satisfied will be create to customer loyalty (Kumar et al., 2017).

\section{Total Quality Management (TQM)}

\section{LITERATURE REVIEW}

TQM in the context of health care environments is defined as satisfaction of patients, doctors, nurses, and suppliers and other interested groups, which can be achieved by implementing 
effective planning, programs, policies and strategies, humans and all other assets efficiently and sustainably (Arasli, 2002). The aim of TQM is to satisfy customers, prevent poor service quality, continual improvement, and measure performance and identify opportunities, maintain improvements, and eliminate sources of cost inefficiency (Mohammad, 2005). TQM's philosophy is customer satisfaction, quality improvement and competitive advantage that emphasize the involvement of all shareholders (Antony et al., 2002). The successful implementation of TQM in hospitals can improve service quality, improve patient satisfaction, improve performance, and reduce operational costs (Talib et al., 2011). TQM has been considered a strategic and operational tool to gain competitive advantage. These advantages can be seen through performance improvements that are quantitatively expressed as productivity, patient satisfaction, flexibility and effectiveness (Irfan et al., 2012; Irfan \& Kee, 2013). Some conceptual factors that trigger success affect TQM implementation in Malaysia, namely culture, honesty, teamwork, sustainable empowerment, education and training, high management commitment to quality and continuous quality improvement. The success of TQM implementation can be observed in its real impact on the company, namely profitability growth, productivity, output quality, user negative and positive assessment, competitiveness, reduced costs, production, stocks, delivery time, process security, ability to develop, and firm marketing resilience (Haming \& Mahfud, 2014).

\section{Kaizen}

The term Kaizen comes from Japanese, namely the words KAI [改] and ZEN [善]. The word "KAI" which is translated into Indonesian means "change" while "ZEN" which means "good". So if interpreted directly then the meaning of Kaizen is to change for the better (Palmer, 2001). Kaizen is only successfully implemented properly when using the right human resources because humans are the most important dimension in improving quality and productivity (Imai, 2001). Kaizen focuses on improving the quality of processes in an organization through reducing cycle times, operating costs, creating continuous flows, customer satisfaction and eliminating waste (Rouf et al., 2017).

Kaizen implementation has a goal, such as making organizations learn better through small incremental changes towards improvement known as Kaizen events, associating with work culture to get endless improvements in quality and productivity efficiency, eliminating hidden costs from 7 (seven)seven waste) in the production process such as overproduction, waste of time, transportation waste, inventory waste, excess processing waste, motion waste, and production defects, provide added value to production operations so as to improve the quality of products at the lowest cost, shorten delivery times to customers, and make changes in a relatively short time and low cost (Paul \& New, 2003). Kaizen can improve operational efficiency, improve service quality and reduce operational costs (Bwemelo, 2016), stating that the 5S-Kaizen-TQM practice can increase employee commitment and motivation, reduce waiting time and increase patient satisfaction (Take et al., 2015).

\section{Operational performance}

Operational performance refers to the ability of hospitals to reduce management costs, improve service cycles, increase service use efficiently (Heizer \& Render, 2008). Operational performance refers to increasing production effectiveness, creating high-quality services (Kaynak \& Hartley, 2008). Operational performance has an important role in each hospital, because it can significantly affect patient satisfaction and loyalty (Slack et al., 2010). Operational performance has a significant effect on organizational performance through management of hospital operational management. 
Operational management is concerned with how efficiently and effectively a hospital uses resources to meet patient expectations and needs (Kumar et al., 2010). Operational performance is measured through indicators of quality, cost, reliability, speed and flexibility (Slack et al., 2010). Operational performance provides various benefits in various aspects such as reducing costs, improving service quality, improving financial performance and patient satisfaction (Heizer \& Render, 2008; Kaynak \& Hartley, 2008).

\section{Service quality}

Based on total quality management perspective, quality is a dynamic condition that relates to products, services, human resources, processes, and environments that meet or expectations (Goetsch \& Davis, 2014). Quality has become an important issue because it has a significant relationship with earnings, cost and stock savings, the quality of health services as consistency in satisfying patients by providing quality, effective and efficient health services in accordance with clinical guidelines and standards (Mohammad, 2005).

The quality of hospital services can be examined from three measured, namely: (a) structure (physical facilities, equipment, funds, health and non-health personnel, and patients); (b) the process (hospital management includes interpersonal, technical and nursing services management all of which are reflected in medical actions and medical procedures for patients); (c) outcome. The service quality significantly contributed on differentiation, positioning, and competitive strategy. In summary, the benefits of superior quality include greater customer loyalty, greater market share, higher stock prices, higher product or service selling prices, and greater productivity (Tjiptono \& Gregorius, 2016). Based on empirical research concludes that contributions from service quality advantages are positively related to profitability, market share, ROI (return on investment), asset turnover, cost efficiency, customer satisfaction, customer loyalty, and word communication (Zeithaml, 2000; Olsen, 2002).

\section{Patient satisfaction}

The assessment of service quality from the customer's perspective has been operationalized as customer satisfaction where in the hospital context patient satisfaction (Ygge \& Arnetz, 2001; Jackson et al., 2001; Zineldin, 2006). Service quality is closely related to patient satisfaction (Tjiptono \& Gregorius, 2016). Patient satisfaction is feeling happy or disappointed from the patient resulting from comparing perceived of service performance in relation to expectations (Kotler, 2000). Patients who are happy will feel satisfied and provide specific benefits to the hospital as patients more adhere to the doctor's advice on treatment, shorten the healing period, and improve health in general (Ramli \& Sjahruddin H., 2015; Yeh et al., 2018). But patients who feel disappointed will feel dissatisfied and will lead to complaints, sensitive to prices, creating negative gethoctular communication (worth-of-mouth communications) and not loyal (Fatima et al., 2009). Customer satisfaction contributes to switching barriers, switching costs, and customer loyalty (Bergel \& Brock, 2018).

\section{RESEARCH FRAMEWORK}

Conceptually statements of relationships between research variables are built on relevant theories and the results of previous studies. Theoretical reviews and empirical findings are used as the basis for describing the conceptual framework of the research and are used as the basis for reducing the hypothesis. Demings chain reaction for quality improvement explained that the chain reaction theory states that by improving quality through the service process, costs can be lowered and productivity can be increased and impact patient satisfaction. Management's obligation is to implement TQM as a tool to support quality improvements based on the Kaizen concept. Patient satisfaction is the core in TQM wheels (Deming, 1950). Patient satisfaction is the focus of TQM. To achieve patient satisfaction, continuous 
improvement (Kaizen) and employee involvement (operational employees and managerial employees) are needed in every process of the organization's activities. Without these two activities, the desire to give satisfaction to customers is difficult to achieve (Deming, 1950).

Managing the right of human resources is the most important dimension in Kaizen implementation. Operational performance is one indicator of the measurement of the success of human resource management. Operational performance is part of hospital performance ( $\mathrm{Li}$ et al., 2006; Jahanshahi et al., 2012). Operational performance has various dimensions of measurement such as quality, cost, reliability, speed, and flexibility (Slack et al., 2010). Operational performance measurement aims to evaluate, control and improve the operating process in order to meet patient needs (Slack et al., 2010).

Talib (2011) provides findings that TQM principles, such as top management commitment, team work and participation, process management, customer focus and satisfaction, resource management, organizational and cultural behavior, continuous improvement, and training and education are principles that best to apply to hospitals, that the successful implementation of integrated quality management can improve patient satisfaction, improve service quality, improve performance and reduce operating costs. These results are relevant to other evidence, that Kaizen has a positive and significant effect on patient satisfaction. Patient satisfaction is reflected through a reduction in waiting time, better doctor and nurse attention, better cleanliness and safety, availability of medicines and laboratory facilities (Rouf et al., 2017).

A similar of fact shows that there is a positive and significant influence between the quality of health care services on overall patient satisfaction, that satisfied patients will create communication, buy back, and are not sensitive to price changes (Al-Damen, 2017). Some of these findings get the rebuttal from other researchers, that there are gaps in all dimensions of SERVQUAL. The responsiveness dimension has the largest gap, followed by reliability, tangibility, empathy and assurance (Essiam, 2013). Service quality does not have a significant effect on patient satisfaction. The results of this study also show that patient satisfaction is not only influenced by service quality but also influenced by other factors such as price, cost, product quality and emotional (Irfan et al. 2012).

Based on theoretical and empirical studies, previous research, the research hypothesis is constructed as follows:

1) TQM, Kaizen and operational performance will have a direct positive effect on service quality

2) TQM, Kaizen and operational performance will have a direct positive effect on patient satisfaction

3) TQM, Kaizen and operational performance will have an indirect positive effect on patient satisfaction via service quality (i.e. a mediator effect).

\section{RESEARCH FRAMEWORK}

This study was a survey of 398 patients in 4 hospitals type B in Makassar. The collected questionnaires were analyzed using analysis of a moment structures version. 22 .

\section{Descriptive variables}

\section{RESULTS}

The results of variable descriptions indicate that teamwork $(\mu=4.1969)$, implementation of the plan $(\mu=4.1546)$, competence $(\mu=4.1380)$, physical evidence $(\mu=4.2253)$, and gethok communication (worth-of-mouth communications) $(\mu=4.1672)$, has the highest average value 
according to the patient's perception. Similarly, the results of the validity test the person correlation show $r \geq 0.30$ and reliability from the cronbach's alpha value $\geq 0.70$ (Hasanuddin $\&$ Sjahruddin, 2017).

\section{Confirmatory Factor Analysis}

The test results of confirmatory factor analysis (CFA)show that the indicators that make the biggest contribution to each construct are customer focus $(\lambda=0.836$; $p$-value $=0,000)$, implementation of the plan $(\lambda=0.877$; $p$-value $=0,000)$, service speed $(\lambda=0,863$; $p$-value $=$ $0,000)$, responsiveness $(\lambda=0,843$; $p$-value $=0,000)$, and complaint behavior $(\lambda=0,828$; $p$-value $=0,000)$.

\section{Goodness of Fit}

Goodness of fit (GOF) shows that the model established is appropriate (fit) with the data obtained, because it has met the criteria GOF (Chi-Square $=195.690195 .690 \leq$; Probability $=$ $0.086 \geq 0.05 ; \mathrm{CMIN} / \mathrm{DF}=1.151 \leq 2.00 ; \mathrm{RMSEA}=0.022 \leq 0.08 ; \mathrm{GFI}=0.949 \geq 0.90 ; \mathrm{TLI}=0.991$ $\geq 0.95 ; \mathrm{CFI}=0.994 \geq 0.95$ ).

\section{Hypothesis Testing}

Based on the results of hypothesis testing, it appears that the probability value $\leq 0.05$ and the direct and indirect effects show a positive direction, so it can be summarized as follows:

1) TQM, Kaizen and operational performance partially have an influence it is directly significant positive for service quality.

2) TQM, Kaizen and operational performance partially have a significant positive direct effect on patient satisfaction.

3) TQM, Kaizen and operational performance partially have a significant positive effect on patient satisfaction through service quality. 
Table 1. Hypothesis testing

\begin{tabular}{|c|c|c|c|c|c|c|c|}
\hline Exogenous & $\begin{array}{l}\text { Variable } \\
\text { Mediation }\end{array}$ & Endogenous & P-Value & $\begin{array}{l}\text { Direct } \\
\text { Effect }\end{array}$ & $\begin{array}{l}\text { Indirect } \\
\text { Effect }\end{array}$ & $\begin{array}{l}\text { Total } \\
\text { Effect }\end{array}$ & Results \\
\hline $\mathrm{TQM}_{(\mathrm{X} 1)}$ & - & Servqual $_{(\mathrm{Y} 1)}$ & 0,000 & 0.252 & 0,000 & 0.252 & $\begin{array}{l}\text { Positive } \\
\text { Significant }\end{array}$ \\
\hline Kaizen (X2) & - & Servqual (Y1) $_{\text {(Y) }}$ & 0.000 & 0.429 & 0.000 & 0.429 & $\begin{array}{l}\text { Positive } \\
\text { Significant }\end{array}$ \\
\hline $\begin{array}{l}\text { Operational } \\
\text { Performance }(\mathrm{x} 3)\end{array}$ & - & Servqual $_{(\mathrm{Y} 1)}$ & 0.013 & 0.145 & 0.000 & 0.145 & $\begin{array}{l}\text { Positive } \\
\text { Significant }\end{array}$ \\
\hline $\mathrm{TQM}_{(\mathrm{X} 1)}$ & & $\begin{array}{c}\text { Patient } \\
\text { Satisfaction (Y2) }\end{array}$ & 0.039 & 0.126 & 0,000 & 0.126 & $\begin{array}{l}\text { Positive } \\
\text { Significant }\end{array}$ \\
\hline Kaizen (X2) & & $\begin{array}{c}\text { Patient } \\
\text { Satisfaction (Y2) }\end{array}$ & 0,000 & 0.273 & 0,000 & 0.273 & $\begin{array}{l}\text { Positive } \\
\text { Significant }\end{array}$ \\
\hline $\begin{array}{l}\text { Operational } \\
\text { Performance }(\mathrm{X} 3)\end{array}$ & & $\begin{array}{c}\text { Patient } \\
\text { Satisfaction } \\
(\mathrm{Y} 2)\end{array}$ & 0,000 & 0.358 & 0,000 & 0.358 & $\begin{array}{l}\text { Positive } \\
\text { Significant }\end{array}$ \\
\hline Servqual (Y1) $_{\text {(Y) }}$ & - & $\begin{array}{c}\text { Patient } \\
\text { Satisfaction (Y2) }\end{array}$ & 0.002 & 0.220 & 0,000 & 0.220 & $\begin{array}{l}\text { Positive } \\
\text { Significant }\end{array}$ \\
\hline $\mathrm{TQM}_{(\mathrm{X} 1)}$ & $\begin{array}{l}\text { Servqual } \\
\text { (Y1) }\end{array}$ & $\begin{array}{c}\text { Patient } \\
\text { Satisfaction (Y2) }\end{array}$ & 0.016 & 0.126 & 0.055 & 0.181 & $\begin{array}{l}\text { Positive } \\
\text { Significant }\end{array}$ \\
\hline Kaizen $_{(\mathrm{X} 2)}$ & $\begin{array}{l}\text { Servqual } \\
\text { (Y1) }\end{array}$ & $\begin{array}{c}\text { Patient } \\
\text { Satisfaction (Y2) }\end{array}$ & 0.006 & 0.273 & 0.094 & 0.367 & $\begin{array}{l}\text { Positive } \\
\text { Significant }\end{array}$ \\
\hline $\begin{array}{l}\text { Operational } \\
\text { Performance (x3) }\end{array}$ & $\begin{array}{l}\text { Servqual } \\
\text { (Y1) }\end{array}$ & $\begin{array}{c}\text { Patient } \\
\text { Satisfaction } \\
(\mathrm{Y} 2)\end{array}$ & 0.048 & 0.358 & 0.032 & 0.390 & $\begin{array}{l}\text { Positive } \\
\text { Significance }\end{array}$ \\
\hline
\end{tabular}

\section{DISCUSSIONS}

\section{Effect of total quality management on service quality}

TQM philosophy is satisfaction, quality improvement and competitive advantage by involving all employees in the organization (Irfan et al., 2012). The results of hypothesis testing from this study indicate the $p$-value is a $0,000<0.05$ and factor loading value is a 0.252 . This means that TQM has a significant positive effect on service quality. Because the coefficients are positively marked mathematically, the increasing intensity of achievement of TQM, the quality of services will also increase. These findings support the total quality management theory (Deming, 1950) which states that any continuous improvement of work methods and processes will be able to improve service quality, costs and productivity, return on investment, and in turn improve competitiveness. The results of this study are in line with the themes of previous researchers (Irfan \& Kee, 2013) which show that TQM has a positive and significant effect on service quality. Furthermore this research also confirms that the dimensions of customer focus, information and analysis are closely related to service quality.

\section{Effect of Kaizen on service quality}

The Kaizen concept is an approach that can only succeed well when accompanied by the right human resource efforts. Human factors are the most important dimension in improving service quality. Hypothesis test results from this study indicate that the p-value is a $0,000<0,05$ and the factor loading value is a 0,429 . This means that Kaizen has a positive and significant effect on service quality. Because the coefficients are positively marked mathematically, the intensity of Kaizen achievement increases, the service quality will also increase. The results of this study 
are in line with the Deming Cycle or Plan-Do-Check-Act (Deming, 1950) that constant and continuous improvement of service systems will improve quality and productivity, which in turn will constantly reduce costs.

The results of this study are in line with previous research, that Kaizen has a positive and significant effect on the quality of health services. That the implementation of Kaizen has an impact on reducing waiting time, higher attention from medical staff, better security systems, improvements in facilities and infrastructure (Rouf et al., 2017). Kaizen applies to public services and can improve operational efficiency, service quality and reduce operating costs, that the government must adopt Kaizen and include it in all public sector reform programs as a strategic tool towards increasing the effectiveness of overall public service organizations (Gordian, 2014). The application of 5s-Kaizen has a positive and significant effect on service excellence in hospitals in Malaysia (Hamid et al., 2016).

\section{Effect of operational performance on service quality}

Empirical research shows that operational performance has a significant effect on organizational performance through management of hospital operational management. Operational management is concerned with how efficiently and effectively a hospital uses resources to meet patient expectations and needs (Kumar et al., 2011). Hypothesis test results from this study indicate that the p-value is a $0.013<0.05$ and factor loading value is a 0.145 . This means that operational performance has a positive and significant effect on service quality. Because the coefficients are positively marked mathematically, the increasing intensity of achievement of operational performance, the quality of services will also increase.

The results of this study support the view according to quality management theory (Crosby, 1962) that efforts to improve service quality can only be achieved if hospitals improve operational employee competencies through providing training appropriately, encouraging employees to correct errors in service and taking notes of problems, and ensuring that all shareholders in the organization understand the steps towards quality. Operational performance has a positive and significant effect on service quality. Improvements to operational performance have an impact on reducing patient waiting time; communication between employees and patients is increasingly (Padma, 2009).

\section{Effect of total quality management on patient satisfaction}

Empirical research shows that TQM as a predictor has a positive and significant effect on performance improvement, increased productivity and patient satisfaction (Sakthivel et al., 2005; Terziovski \& Morgan, 2006; Lagrosen, 2007). The results of hypothesis testing from this study indicate that the p-value is a $0,000<0.05$ and the factor loading value is a 0.126 . This means that TQM has a positive and significant effect on patient satisfaction. Because the coefficients are positively marked mathematically, the increasing intensity of achievement of integrated quality management, the patient satisfaction will also increase. The results of this study are in line with the opinions expressed by Deming (1950) that patient satisfaction is the focus in integrated quality management.

To achieve patient satisfaction, continuous quality improvement and employee involvement are required in every process of the organization's activities. Without these two activities, the desire to give satisfaction to the patient will be difficult to achieve. Similarly, the results of this study support the Deming's chain reaction theory, in which this theory confirms that any continuous improvement of work methods and processes will provide a series of results such as improvements human quality, process quality and environmental quality. It is impossible to produce quality services without going through human and quality processes. Patients who 
have experienced quality services will create trust, satisfaction and become loyal patients, so that it will increase hospital profits. Loyal patients will use the same service at least three times, inviting friends or family to use the same services used by patients. , discussing positive things with others, this is a free promotion. Empirical facts provide evidence that the successful implementation of integrated quality management has an impact on improving patient satisfaction, improving service quality, improving hospital performance, and reducing operational costs (Talib et al., 2011).

\section{Effect of Kaizen on patient satisfaction}

Total quality management is inseparable with continuous efforts to make improvements; continuous improvement is based on the Kaizen concept, which is always looking for ways to improve operations. Empirical research has shown that effective Kaizen implementation can reduce operational costs and improve patient satisfaction (Rouf et al., 2017). The hypothesis test results from this study indicate that Kaizen has a positive and significant effect on patient satisfaction, the p-value is a $0,000<0.05$ and the factor loading value is a 0.273 . This means that Kaizen has a positive and significant effect on patient satisfaction, because the coefficients are positively marked, then will increase the intensity of achieving Kaizen, then will also increase patient satisfaction. Kaizen has a positive and significant effect on patient satisfaction. Kaizen application can reduce service process time from 75.40 minutes to 57.85 minutes and patient satisfaction score increases from 84,00 to 91,90 (Sobek, 2012).

The 5S-Kaizen as a CQI method (continuous quality improvement is a very effective) to improve the hospital service environment and patient satisfaction (Kamiya et al., 2016). Different results, that the implementation of $5 \mathrm{~s}$-Kaizen-TQM practices at regional referral hospitals did not have a positive and significant effect on patient satisfaction (Take, 2015). The occurrence of research contradictions caused by the application of Kaizen is limited to certain service units and has not been applied to the overall service unit.

\section{Effect of operational performance on patient satisfaction}

Operational performance refers to increasing the effectiveness of production, creating highquality services, patient satisfaction, increasing revenue and company profits (Kaynak \& Hartley, 2008). Empirical research shows that operational performance has a positive and significant effect on patient satisfaction and loyalty (Slack et al., 2010). Hypothesis test results from this study indicate that operational performance has a positive and significant effect on patient satisfaction, the p-value is a $0,000<0.05$ and the factor loading value is a 0.358 . This means that Kaizen has a significant positive effect on service quality. Because the coefficients are positively marked mathematically, the increasing intensity of achievement of Kaizen, the patient satisfaction will also increase. The results of the study are in line with the research by Kumar et al. (2011), shows that the speed of service, quality, reliability and flexibility of operational employees can increase patient satisfaction and lead to customer loyalty.

\section{Effect of service quality on patient satisfaction}

Quality health services are a health service needed, in this case the health care profession, and at the same time desirable both by patients and the community and affordable by people's purchasing power (Imbalo, 2002). The hypothesis test results indicate that service quality has a positive and significant effect on patient satisfaction with the p-value is a 0,000 $<0.05$ and loading factor value is a 0.252 . This means that service quality has a significant positive effect on patient satisfaction. Because the coefficients are positively marked mathematically, the increasing intensity of achieving service quality, the patient satisfaction will also increase. 
There is a positive and significant influence on patient satisfaction (Nguyen, 2012; Fatima et al., 2018).

There are gaps in all SERVQUAL dimensions. The responsiveness dimension has the biggest gap, followed by reliability, physical means, empathy and assurance. The results showed that patient satisfaction was strongly influenced by responsiveness, followed by empathy, assurance, physical means (Essiam, 2013). This study contributes to hospital administrators, stakeholders and academics to investigate the relationship between SERVQUAL dimensions and patient satisfaction using a regression hierarchy model. Furthermore, this finding is in line with the findings by Irfan et al. (2012) that service quality does not significantly influence patient satisfaction. This is because the services offered by hospitals are not in accordance with the expectations and desires of patients. On the other hand the price, cost, and management of total quality management need to be the basis of consideration in order to improve patient satisfaction.

\section{Service quality as a mediating variable. Effect of total quality management on patient satisfaction}

The Sobel test results show that the effect of total quality management on patient satisfaction through service quality can be proven by the p-value is a 0.016 and the factor loading value is a 0.055. This means that TQM has a positive and significant effect on patient satisfaction through service quality. Therefore marked mathematical coefficient is positive, then increasing the intensity of the achievement of TQM; the patient satisfaction will also increase through service quality. The results of this study are consistent with findings from previous studies showing that TQM soft aspect and hard aspect has a positive and significant effect on customer satisfaction through service quality at commercial banks in India (Lenka et al., 2010). Commitment and job satisfaction from employees will increase affective commitment and leadership in the workplace spiritually and transformational, which is considered a soft aspect of TQM. In addition, improving service quality is also influenced by management information systems, which represent the hard aspects of TQM. Increasing the customer satisfaction with the service quality role can be provided by the soft hard and hard aspect of TQM.

\section{Service quality as a mediating variable. Effect of Kaizen on patient satisfaction}

The result of the Sobel test show that the effect of Kaizen on patient satisfaction through service quality can be proven through the p-value is a 0.006 and the factor loading value is a 0.094. This means that Kaizen has a positive and significant effect on patient satisfaction through service quality. Because coefficients are positively marked mathematically its means, the intensity of Kaizen achievement increases, so patient satisfaction will also increase through service quality. Thus hospitals that apply Kazien well then service quality increases and impacts patient satisfaction. Service quality will be achieved if the hospital can increase satisfaction with internal and external customers. Employee satisfaction as an external customer can create quality internal services resulting in loyalty and ultimately will encourage the creation of value of external services that affect patient satisfaction.

\section{Service quality as a mediating variable. Effect of operational performance on patient satisfaction}

The Sobel test results show that the effect of operational performance on patient satisfaction through service quality can be proven by the p-value is a 0.032 and the factor loading value is a 0.048. This means that operational performance has a positive and significant effect on patient satisfaction through service quality. Because the coefficients are positively marked mathematically, the increasing intensity of achievement of operational performance, the 
patient satisfaction will also increase through service quality. Thus hospitals that improve operational performance properly, service quality increases and impacts patient satisfaction.

\section{CONCLUSIONS}

TQM, Kaizen and operational performance used in services at Type B hospitals in Makassar have proven to be able to improve patient service quality. TQM, Kaizen and operational performance provided are proven to increase patient satisfaction. Service quality is proven to be able to play its role as a mediating variable in analyzing TQM, Kaizen and operational performance towards patient satisfaction through service quality. The hospital management to always improve the quality of services so as to increase patient satisfaction, but this is inseparable from the management of TQM, Kaizen and operational performance well. The advanced researchers are expected to develop the results of this study by adding several constructs and increasing the number of respondents and using outpatients as a unit of analysis.

\section{References}

Al-Damen, R. (2017). Health Care Service Quality and Its Impact on Patient Satisfaction "Case of Al-Bashir Hospital". International Journal of Business and Management, 12 (9), 136.

Antony, J., Leung, K., Knowles, G., \& Gosh, S. (2002). Critical success factors of TQM implementation in Hong Kong industries. International journal of quality \& reliability management, 19 (5), 551-566.

https://doi.org/10.1108/02656710210427520

Arasli, H., \& Ahmadeva, L. (2004). "No more tears!" A local TQM formula for health promotion. International Journal of Health Care Quality Assurance, 17 (3), 135-145. https://doi.org/10.1108/09526860410532775

Bergel, M., \& Brock, C. (2018). The impact of switching costs on customer complaint behavior and service recovery evaluation. Journal of Service Theory and Practice, 28 (4), 458-483. https://doi.org/10.1108/ISTP-02-2017-0035

Bwemelo, GS (2016). Improving Public Service Delivery in Tanzania Through Kaizen: A Review of Empirical Evidence.

Carton, RB (2004). Measuring organizational performance: An exploratory study (Doctoral dissertation, University of Georgia).

Central Intelligence Agency (CIA). (2018) www.odci.gov/cia/publications/factbook.

Deming, WE (1950). Elementary principles of statistical control of quality: a series of lectures. Nippon Kagaku Gijutsu Remmei.

Essiam, JO (2013). Service quality and patient satisfaction with healthcare delivery: empirical evidence from patients of out patient department of a public university hospital in Ghana. European journal of business and management, 5 (28), 52-59.

Fatima, T., Malik, SA, \& Shabbir, A. (2018). Hospital healthcare service quality, patient satisfaction and loyalty: An investigation in context of private healthcare systems. International Journal of Quality \& Reliability Management, 35 (6), 1195-1214. https://doi.org/10.1108/IJQRM-02-2017-0031

Goetsch, DL, \& Davis, SB (2014). Quality management for organizational excellence. Upper Saddle River, NJ: Pearson.

Gordian, B. (2014). KAIZEN as a Strategy for Improving SMEs' Performance: Assessing its Acceptability and Feasibility in Tanzania.

Hamid, NAA, Hisham, MHB, \& Abdullah, NH (2016). The Development of 5s-Kaizen And Service Excellence Measurement Framework for Malaysia Private Hospitals.

Haming, M. \& Mahfud N. (2014). Modern Production Management: Manufacturing and Service Operations 1. Jakarta: PT. Bumi Aksara

Hasanuddin, R., \& Sjahruddin, H. (2017). The Structure of Emotional Intelligence, Spiritual Intelligence and Its Relationship with Work Enthusiasm and Auditor Performance. World Journal of Business and Management, 3(1), 67. 
Heizer, JH, \& Render, B. (2008). Operations management (Vol. 1). Pearson Education India.

Hyland, PW, Milia, LD, \& Terry, RS (2004). CI Tools and Technique: Are there any difference between firms. In Proceedings 5th CINet Conference, Sydney, Australia.

Imai, Masaaki. (2001). Kaizen (Ky zen). (Interpreting: Dra. Mariani Gandamihardja). The Key to Success in Japan in Competition. Management Series. Custodian Library. Pressindo, Jakarta.

Imbalo, Pohan, S. (2002). Quality Assurance of Health Services. Jakarta: Medical Book Publishers.

Irfan, SM, \& Kee, DH (2013). Critical success factors of TQM and its impact on increased service quality: A case from service sector of Pakistan. Middle East Journal of Scientific Research, 15 (1), 61-74.

Irfan, SM, Ijaz, A., \& Farooq, MM (2012). Patient satisfaction and service quality of public hospitals in Pakistan: an empirical assessment. Middle-east journal of scientific research, 12 (6), 870-877.

Jackson, JL, Chamberlin, J., \& Kroenke, K. (2001). Predictors of patient satisfaction. Social science \& medicine, 52 (4), 609-620. https://doi.org/10.1016/S0277-9536(00)00164-7

Jahanshahi, AA, Rezaei, M., Nawaser, K., Ranjbar, V., \& Pitamber, BK (2012). Analyzing the effects of electronic commerce on organizational performance: Evidence from small and medium enterprises. African Journal of Business Management, 6 (22), 6486-6496. https://doi.org/10.5897/AJBM11.1768

Kamiya, Y., Ishijma, H., Hagiwara, A., Takahashi, S., Ngonyani, HA, \& Samky, E. (2016). Evaluating the impact of continuous quality improvement at hospitals in Tanzania: a cluster-randomized trial. International Journal for Quality in Health Care, 29 (1), 32-39. https://doi.org/10.1093/intqhc/mzw128

Kaynak, H., \& Hartley, JL (2008). A replication and extension of quality management into the supply chain. Journal of Operations Management, 26 (4), 468-489. https://doi.org/10.1016/i.jom.2007.06.002

Ministry of Health of the Republic of Indonesia. (2013). Basic health research. Research and Development Agency of North Sumatra Province.

Kotler, Philip. (2000). Marketing Management. Millennium Edition, Prentice Hall Intl, Inc. New Jersey.

Kumar, V., Batista, L., \& Maull, R. (2011). The impact of operations performance on customer loyalty. Service Science, 3 (2), 158-171. https://doi.org/10.1287/serv.3.2.158

Lagrosen, Y., Bäckström, I., \& Lagrosen, S. (2007). Quality management and health: a double connection. International Journal of Quality \& Reliability Management, 24 (1), 49-61.

https://doi.org/10.1108/02656710710720321

Lenka, U., Suar, D., \& Mohapatra, PK (2010). The aspects of quality management practices of influencing service quality and customer satisfaction in manufacturing-oriented services. Global Business Review, 11 (1), 79-101.

Li, S., Ragu-Nathan, B., Ragu-Nathan, TS, \& Rao, SS (2006). The impact of supply chain management practices on competitive advantage and organizational performance. Omega, 34 (2), 107-124.

https://doi.org/10.1016/i.omega.2004.08.002

Mohammad Mosadegh Rad, A. (2005). A survey of total quality management in Iran: Barriers to successful implementation in health care organizations. Leadership in Health Services, 18 (3), 12-34.

https://doi.org/10.1108/13660750510611189

Nguyen, MT. (2012). Effects of service quality and price fairness on student satisfaction. International Journal of Business and Social Science, 3 (19).

Olsen, SO (2002). Comparative evaluation and relationship between quality, satisfaction, and repurchase loyalty. Journal of the academy of marketing science, 30 (3), 240-249. https://doi.org/10.1177\%2F0092070302303005

Padma, P., Rajendran, C., \& Sai, LP (2009). A conceptual framework of service quality in healthcare: perspectives of Indian patients and their attendants. Benchmarking: An International Journal, 16 (2), 157-191.Crosby, PB (1962). Quality management: the real thing. Philip Crosby Associates II, Inc., 1 (3).

https://doi.org/10.1108/14635770910948213

Palmer, VS (2001). KAIZEN inventory management. In Engineering Management for Applied Technology, 2001. EMAT 2001. Proceedings. 2nd International Workshop on (55-56). IEEE.

Paul Brunet, A., \& New, S. (2003). Kaizen in Japan: an empirical study. International Journal of Operations \& Production Management, 23 (12), 1426-1446. https://doi.org/10.1108/01443570310506704

Ramli, A. H., \& Sjahruddin, H. (2015). Building patient loyalty in healthcare services. International Review of Management and Business Research, 4(2), 391. 
Rouf, MA, Debnath, SC, Haque, ME, Chowdhury, ZMR, Hasan, DMM, Zannat, T., \& Rabby, MF (2017). Quality of hospital services in 5S-KAIZEN-TQM implemented secondary level hospital: a cross-sectional study. Asian Journal of Medical and Biological Research, 3 (3), 335-340.

Sakthivel, PB, Rajendran, G., \& Raju, R. (2005). TQM implementation and students' satisfaction of academic performance. The TQM magazine, 17 (6), 573-589. https://doi.org/10.1108/09544780510627660

Slack, N., Chambers, S., and Johnstone, R. (2010). Operations Management. 6th Harlow, England: FT Prentice Hall.

Sobek II, DK, Claudio, D., \& Bischoff, C. (2012, January). Hospitals in the State of Montana. In IIE Annual Conference. Proceedings (p. 1). Institute of Industrial and Systems Engineers (IISE).

Take, N., Byakika, S., Tasei, H., \& Yoshikawa, T. (2015). The effect of 5S - Continuous Quality Improvement - Total Quality Management on staff motivation, patients' waiting time and patient satisfaction with services in Uganda. Journal of public health in Africa, 6 (1).

Talib, F., Rahman, Z., \& Azam, M. (2011). Best practices of total quality management implementation in health care settings. Quarterly Health marketing, 28 (3), 232-252. https://doi.org/10.1080/07359683.2011.595643

Terziovski, M., \& Morgan, JP (2006). Management practices and strategies to accelerate the innovation cycle in the biotechnology industry. Technovation, 26 (5-6), 545-552. https://doi.org/10.1016/j.technovation.2004.10.016

Tjiptono, Fandy. \& Gregory, Chandra. (2016). Service Quality and Satisfaction, Edition 4. Yogyakarta: Andi Publisher.

Yang, CC (2003). The establishment of a TQM system for the health care industry. The TQM Magazine, 15 (2), 93 98. https://doi.org/10.1108/09544780310461107

Yeh, MY, Wu, SC, \& Tung, TH (2018). The relation between patient education, patient empowerment and patient satisfaction: A cross-sectional-comparison study. Applied Nursing Research, 39, 11-17.

https://doi.org/10.1016/j.apnr.2017.10.008

Ygge, BM, \& Arnetz, JE (2001). Quality of pediatric care: application and validation for measuring parent satisfaction with hospital care. International Journal for Quality in Health Care, 13 (1), 33-43. https://doi.org/10.1093/intqhc/13.1.33

Zeithaml, VA. (2000). Service quality, profitability, and the economic worth of customers: what we know and what we need to learn. Journal of the academy of marketing science, 28 (1), 67-85.

https://doi.org/10.1177\%2F0092070300281007

Zineldin, M. (2006). The quality of health care and patient satisfaction: an exploratory investigation of the 5Qs model at some Egyptian and Jordanian medical clinics. International journal of health care quality assurance, 19 (1), 60-92. https://doi.org/10.1108/09526860610642609 